座談會

\title{
化學工業方面への錫の利用（講演並に座談會）
}

（大阪第 15 可座談會要旨）

日 時 昭和 17 年 5 月 20 日（土）後 6.30

會 場 大阪軍人會館 (大阪市東區京橋)

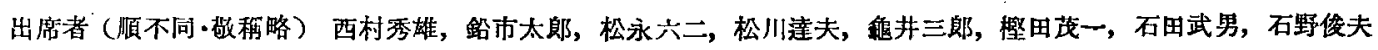
森田利一, 山脇克已, 永田進治, 上山惟恒, 㭼村翼三，根岸元凱，江村毒之，山本武一，横川良章，石高保弘，山内 淑人，柏谷芳郎，岡村 铞，川口壯吉，本莊記一，没漫槙四郎，平井泰造，青井捨三，玉淵安太郎，井今村警三，山

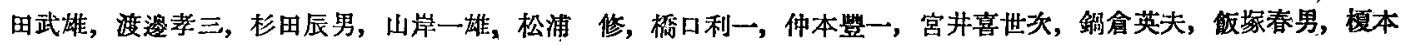

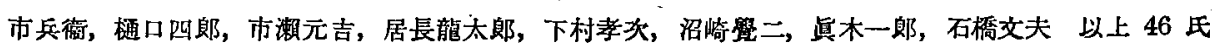

開

策并三郎(京大教授・本會副會長) 本日は「化學工業方面への 錫の利用」に關する座談會で西りますが，錫の一般的利用と諒 解されてい」と思ひます。まつここの面の權威者である西村さん に錫及錫合金の一般の性質に就き括話を願ひ，その後に今後の 錫の利用法に就いて質疑雄答の座談會にしたいと思ひます。錫 は今度の大東亞戰爭で我が國に非常に潤澤に入り，或は過剩の
暝れがありますので，今から對策を講じたいと思ひます。錫は 從來化學工業方面に餘り鹿く使はれて居ませんが，これは錫が 必ずしあ喥蝕に弱いといふのではなく，錫が十分なかつたので 使はなかつたのかと思ひます。それで若し非常に潤澤に入れば 或はその方面の利用の道も開けることと思ひますので，本日は さろいふ方面の質鼠應答を十分に腹藏なくやりたいと思ひま す。それでは西村さんどラか....。

\section{錫及錫 合金の性質に就て}

\section{西 村 秀 雄}

錫及び錫合金につきましてお話申上げますが，錫につきまし てはえを餘り取技つたことがないのでたら゙文犽にありますこと を多少皆さんに御紹介申上げる程度に過ぎないと思ひます。只

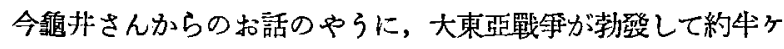
年その間に西南太平洋の殆ど大部分が我が勢力䇛畧になり，各 種の物犋が將來我が國に利用されるやらになりますことは御同 磨に粃へない次第であります。そのうち問題になつて居るもの \一つが,錫であります。

\section{錫の産出狀態}

錫の産出方面はマレー牛島を主としてバンカ島その他に多量 に埋藏されてるるわけであります。或は年涯 7，8 萬 れて居りますが統計を見ますとそれ以上，10 萬 $\mathrm{t}$ 以上出た年 もあります。從來は御承知のや引に英國が錫㓌源を殆ど獨占し 世界の节場を自分に都合の良いやらにコントロールし又價格の 如きも自肉に支配して居つた狀態であります。錫鑬石の純度が

京都帝國大學教授 工學博士
相當よく，その精鍊方法の如きも極く簡單なものであつて，容 易に品位が 99.98 程度まで上げられるすのらしいのであります がその方法は文蹼にも出てるないといふ事情であります。錫資 源が鬼に解豐富で我が國の今迄の使用量の數倍或は 10 倍近く も多く㿷出するのでありますから，やがては過剩になるだらら といふ慜念が抱かれてるるのであります。

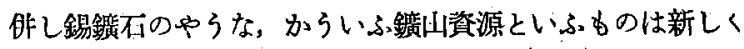
創造することは難かしい。むしろ出來ることならばこれは大切 なりのとしてそのま」放置して必要以外は探風しないのが一番 賢明な策であらろと思ひます。然し或程度の金屬を生德して置 かないといざとなつてはまた精鍊設備が容易に出來るものであ りませんから，製造が不可能になります。常々相當量の生㡾は 續けて行くことが必要にならうかと思ひます。さらいる意味で どうしても錫の使用といふことは今から考へて固いて無䭾でな いと思ひます。

\section{錫 の用途}

今までどういふ方面に使はれて居たかをまゔ第一に申上げて 
㯰きます。錫の一番多く使はれて居るものはブリキ板郎ち錫鍍 金鐵板であります。これは耀詰の䌯及び石油䌯，その他各種の 用途を持つて居りまして、これが世界的に一番大きな消費面て あります。その他は比較的少く，その主なものを申上げて置き たいと思ひます。

合金としては古くから所謂砲金或は靑銅といはれて居る銅合 金であります。鑄造用の銅合金であれば 10\% 附近の錫のもの が多く使用されて居ります。それからまた加工用の燐青銅方面 になりますと $7 \%$ 程度のものが普通であります。その他錫 14 〜15\%のものに䊖承に使はれてるる憐青銅があります。さろ いふ風に青銅或は砲金は相賞多く使はれて居り，殊に比較的海 水に强いため船舶方面に非常に多く使はれて居ります。それか らまた黄銅方面に於てはネーバル黄銅，郎ち四六黄銅に錫を入 れたものが船舶方面に用るられて居りました。最近は餘り使は れて居りませんが，以前は七三宣鍮に $1 \%$ 錫を大れたてドミラ ルチイ黄銅が復水器管郎ちコンデンサー・チューブに多く使は れて居つたのであります。それから錫を主體とした合金は餘り 使用方面は澤山なく，軕洀の合金バビ。ト・メタルといはれて 居りますりのが，かなり多量に使はれて居ります。これはアン チモニー，銅が含まれた合金であります。これす成分がいるい ろあり，目的によつて變つて居りますが，銅が $3 \%$ 位から多く なりますと $7 \%$ ，アンチモ=ーb 3〜4\% 加ら多いのは 12〜13 \%位のすのあります。さういふ風な錫を主體にしたバビット 式の軸承，その他鉛が主體の輏承合金にも多少錫の入れて居り まナし，ま大錫が 40\% 程度のものて鉆と錫を主體にした軸承 合金が便利でありますためかなり色々使はれて居つたやうであ ります。それから活字合金は鉛が主體でありますが，これも多 少錫を入れて居ります。それからハンダに多く錫を使ふことは 御承知の通りで，これもいろいるな成分がありますが，50\%の 鉛と錫の合金であるとか，鉛が 60 で錫が 40 であるとか，或 は鍇管の接合などに使ふものは鉆が $70 \%$ 錫が $30 \%$ で之れを 外國ではワイピング・ソルダーといはれて居ります。これ位の すのが合金として多く使はれて居ります。その他, 銅線の表面 に鍍金してゴムに含まれて居る硫黄の作用を防ぐやうに以前は やつて居りましたが，事變以來とれが禁止の形になつて居りま

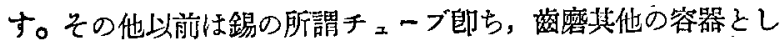
て用ひます押出しチニーブに錫を使つて居りました。沿我が國 で所謂銀紙といはれて居りました錫籍も現在ではアルミ箔が多 く使はれて居りますが，鍇の表面に錫を $10 \%$ 位に薄く被せま して，各種の包裝用に使つて居つたのであります。

民需用の方面で、, 装飾品としての花器, その他の食器類等 に所謂錫器具としてかなりの量が使はれて居り。车我か國では 餘り゙使はなかつたやらですが, 海外ではブッタニャ・メタルと
云ふ名称でアンチモニーや鉛の合金にしまして，スプーン等の 食器方面にかなり使はれて居つたやらであります。ブリキ板 以外に於きましてはその量は大して多くないと考へて居りま t。

\section{錫及錫合金の物理的性算}

錫が若し餘つた場合にどろいふ方面に使つたらい」かを考 る場合には，錫の性澌並泟錫合金の性質を知る必要がありま

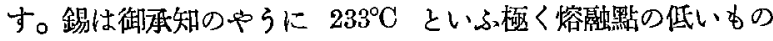
で, 非常に軟かい鉛のやうなもので涱り强さが $1.5 \mathrm{~kg}$ 程度の 極く弱いものであります。鉆之同樣に常溫加工しても常溫で再 結晶するために固くならない金屬の一つであります。ですから 錫に外力を加へて置けば所謂クリープ現象を起すので力の掛る ところにはそのま」使ひ得ない譯であります。又錫は常温では ※錫といふ正方晶形の結晶のものであります。その變態點は常 温に於きまして $13^{\circ} \mathrm{C}$ 或は $18^{\circ} \mathrm{C}$ と云はれて居りますが，これ が $\beta$ 錫になればダイヤモンド型の結晶格子を取るやうになり ます。所謂灰色の錫となりますと粉になつてしまふので，所謂 錫の病氣チン・゙ストと申し使用上槺はれて居ります。チン・・ ストになる反應は $40^{\circ} \mathrm{C}$ 位で最も進行し易くなります。常溫で は餘りその現象が見られない譯で，從つて錫を低温で使用する ことは禁物であります。作しながら多少不純物として他の金犀 が大りますとこの現象す餘程押へられることになつて居りま す。例へば荅鉛のやうな金屬が少量含まれると㱠どチン・ベス トの現象を見ないと云はれて居ります。

次に皆さんがお使ひにならうとすれば，どらしても化學的方 面を考へて，化學的性筫をまづ知らなくてはなりません。錫が

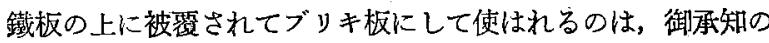
やろに錫が比較的銹び難いといふ點を利用したもので，鐡に對 しては電解的に申しますと鐵よりはプラス郎ち貴な金風であり ますために鐵の䳸蝕を防ぐ譯でなく，表面を被覆して磨蝕を防 止してるるに過ぎないのですから，一旦孔が明けばそこから中 の鐵はよく銹びて行く譯であります。

錫の合金が弱いからもつと强いものが出來ないかといるいる ・調べて見ますと，强い金愿を得るためにはどうしても固溶體合 金とする必妧がありますので，錫と固溶體合金を相當廣い範国

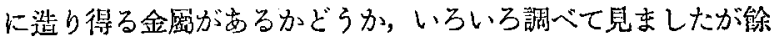
りありません。多くの金蚝は中間の化合物を作るものが多いや らであります。僅かにアンチモニーが最高 $10 \%$ 国溶するので あります。從つてアンチモニーがよく錫と一緒に使はれるので あります。でも大して强くなりませんので，力を求めるといふ ことは錫を主骾としたものでは不可能であるといか風に考へら れるのであります。 


\section{化學的性算}

化學的性婜としては多少とも錫を贵金圆のや引に取技つて， 出來るだけ鋁を使はないといらことのみを考へてるたので筫際 に研究を狳りやつて居りません。且文践も大した交践もないの でありますが，各種の化學液に對する歷蝕の程度を多少申上げ て置きたいと思ひます。

まづ第一に硫酸, 監酸, 硝酸のや引な酸に對しては 2,3 の 研究の結果によりますと、之等のらち硝酸が一番腐玲致します。 さろして硫酸がー番作用が弱いことになつて居ります。殊に酸 素の含まれるといふことか應蝕を促進します。一般にさらです が，酸素の存在が甚だしく㦄蝕を助けるといふっととになつて居 ります。硫酸を使用して山酸素のために酸化錫が出來まして, それで硫酸の腐蝕を防いで吳れるといふやらなことは馀り期待 出來ないと思ひます。

それからハロゲンの酸になりますと臭素酸，沃素酸の如きも のは錫をよく传すやうでありまして，塩酸はそれよりは多少作 用が弱く，弗酸が一番弱いといふ結果が與へられて居ります。 からいふ各種の酸に對しまして不純物として銅, 鉆, アンチモ ニー，その他の金㳟が含まれて居りますと甚しく腐蝕されると いふ風になつて居ります。

それから有機酸でありますが，有機酸に對してはこれは割合 に研究が出柬て居りますが，恐らく罐詰などに使ひますために ブリキ板としての性質を知るために調べたのであらうと思はれ ます。その 2,3 の例を申しますと，徐酸，酒不酸，构格酸，

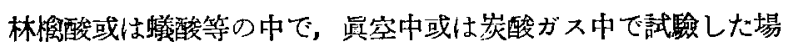
合には㱠ど錫は變化がなく，空氣に触れた場合に極く僅か麻玲 が行は杜るといふ結果が與へられて居ります。それからまたビ クリン酸のやろなものはやはり水であるとか宾氣がなければ作 用しません。かういふ風に在䊩的な酸に對しますと割合に强い のであります。

それからアルカリては例へばアムモニア, 炭酸曹暹, 菏性曹 達などで試驗した結果は、アムモニア及び岸酸曹達溶夜では馀 り磨蝕は起らないが，苛性薯達の中では極く僅が腐触されま す。作し苛性加里では相虽歷玲します。

それからガス體になりますとハロゲンのガスは乾懆狀態です 作用し，祭素及び臭素のやうなるのは常溫でもよく作用すると

\section{座談}

西井只今から座談會に移ります。鍇先坐に座長をお願ひした いと思ひます。どうぞ宜しく。

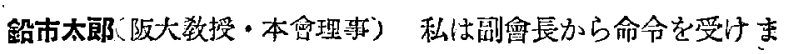

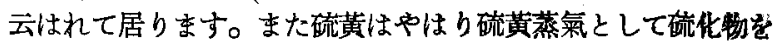
作り，硫化水素b $100^{\circ} \mathrm{C}$ 迄は餘り作用しませんが, $100^{\circ} \mathrm{C}$ 以上 になりますと硫化物を作ります。作し以上は單に錫としての性 質でありまして，合金に就ての研究は殆ど行はれて居りません。 これは今まで合金をさらいふ方面に使ふといふことが殆ど考へ られて居らなかつた結果ではないかと思ひなす。然しながら錫 を自由に使ひ得るやうな時代が將来來るとすれば，やはりさう いふ方面も調べて行く必要があるのでないかと思ふのでありま

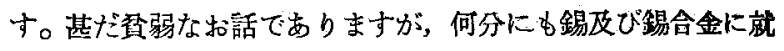
きましては從來はむしろそれを使はないやるにする，錫でない とどらしても都合が惡いといふるもののみに錫を使つて居た結果 として俆り研究が進んで居らん譯であります。

將來は段々と錫の用途を考へて行けば必ずもつと多くなるを 思ひますが，その一例を申上げますと，先程軜事合金に橉青鈮 のやろなもの，或は鉆の大つた銅或はバビット・タルのやる なるのを使ふといふことを审上げましたが，一方錫は餘剩にあ つても銅合金ならば銅は非常に足りませんから，それを使つて 合金を作ることはこれは香た不可能であります。どうしても銅 のやうな不足資源を使はないで錫を使ふといふっとに頭を使ば なくてはならぬと思ひます。

その一例は，例人ば現在は未だ餘つてるるとは电し萐极ます が，アルミニウムの如き特來資源的に困らない金屬を主體比し て，錫を大れた合金が使はれるるやになるのであらすと考へら れるのであります。これは既に名古屋帝大久恒博土が秋の方で 研究を始められ，アルミニウムに錫を入れためのが軸承金雷と して大體一番成績がい」そいふことが判りました。金屬凬會て も發琵し，同時に陸軍航空技術研究所でも同樣に卸研究になつ てその研究結果もこちらのと大體同じやうなところに到達し; 錫を入れたアルミニウムの合金がよいと云ふことになつて居り ます。之には多少銅を使つてあ極く少量で濟むのであります。 さらいふ合金加軸承として相當使へること方制り，その後陸軍 でずつと研究され既に賽用化されてるるところるあるやうに承 つて居ります。そ引いふ風に將來とも研究を進めまして豐富に 使用し得る金稉を有呚に使ふといふことにしたいと思つてるる 次第であります。

簡單でしたが皆さんの座談會に移られるお話の絲口を申上け たといふ意味で御諒承を願ひたいと思ひます。（拍手）

\section{會 （西村氏を中心に）}

したが，錫の座談會に錩ですから，他のことは鬼に角、その點 たシけは邀當でありりま寸(笑政)。唯今西村博士から錫及び錫合金 の化學的性筫，物理的性筫——殊に筸さんには化學的の性筫为: 
代學機祴でも重要と存じますがーに就てお話があり，更に南 洋方面に於ては錫の資源が過剩になる狀態にあるとのことです が，技術院です過剩凟源の對策の委員會を開き，西村博士と共 に私与出席致しました。

その席上でもいろいる話が出ましたが，問題は甚た度箱圍に 入うて來て，他の物資の過剩，ゴムの過剩といふことにも關聯 して，ゴムの充塤齋として亞鉛華の代りに酸化錫を使つたら值 段は違ふが性貿がよくなるといふことも考へられて居りました がぞの結果どういふ方面に重點を置いたらい」かといふこと は餘り範囯が虚くなつて難かしくなるのであります。今夜は化 學㙨械協會の錫の座談會で「化學工業方面への錫の利用」とい ふのでありますから，錫の性器等に就いて御澌問を願ひ，西村 博土に拉答一を願ふことが適當かと思ひます。

今お話の通り，酸或はアルカリに比較的侵されない、錫が過剩 にあるのでから，皆さん御腹藏なく，御質問なり出考へを述べ て頂きそれれはどらす少し無理だららといふ風に結諭の附け ば、それはそれです非常に結構であります。又, それでよから ろといふことになつて，望際にさういふ方面に錫を使用するや らになれば，國家のためにも化學工業界のためにも誠に良いこ とであると思ひます。值段は相當現在は高いですが南泎の立派 な鐴不を使へば簡單で今日の時價の牛分位安くなり得ると思は れます。これから始めますが，今晚特別に御招待した方から打 話を願ひ，それから後自由に御意見を伺ひます。先づ松川博士 に化學工業方面への錫の利用に關し何か未願ひしたいと思ひま to

柃川㵆夫(阪大教授) 先程西村先生の括話のや引に錫が今まで 餄り使はれて居りませんのて，それに對する研究む我々も稌り 眼を通して居りません。たが少しばかり錫の合金のデーターを 集めましたがそれだけでも200ばかりあります。性質に就ては 書物にも無し，筫際に馀り使はれませんので，特に申上げるこ ともありませんっ將來の利用方面に就ては皆さん方の御意見を 承り，御要求に道寸るやらな合金を出來るだけ研究して作りた いと思ひます。余り知識を持つて居りませんので残念に思つて 居りすが........

鉛(座長) 松川博士は皆さんからいろいる御意見が忚ました節

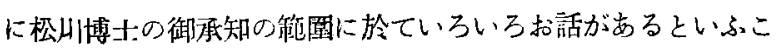
とですから，それでは不田さんに㹂金その他の上から見ました 御意胃を……。

\section{錫 の 鍍 金}

石田武男(大阪市立工業研究所技師）私は電氣鍍金の方で錫も 少取报つて居りますが，化學機栈には錫鍍金は餘り使はれて 居り京せん。先程西村先生の括話のやうに殆どブリキの代用と

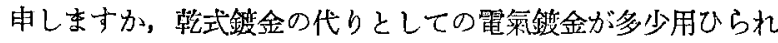
て居つた狀態で，大東亞戰争以前には錫の篩約の目的で乾式の 一部分に電宩鍍金が用ひられてるた程度であります。從つてこ れに關する研究嚾かでありますが外國に於ては相當研究が行 はれて居つたやうであります。

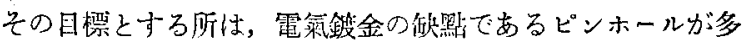
いとか光澤がないのを改良する事に䋰つて居らまして，电澤の ある乾式鍍金に近い、鋁鋌金を施したいといふので，研究が進め られて居つたやうであります。その結果發表されましたのが普 通の亞錫酸ナトリウム溶液とか焦性獜酸錫ナトリウム溶液の代 りに鈿酸ナトリウム溶液を用ふる片法であります。此の溶液を 使つて見ましたが，從來のむのよりは多少光澤がありますが乾

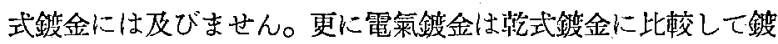
孔が多いために，そのところから鐵鉟が發生するといふ触點が

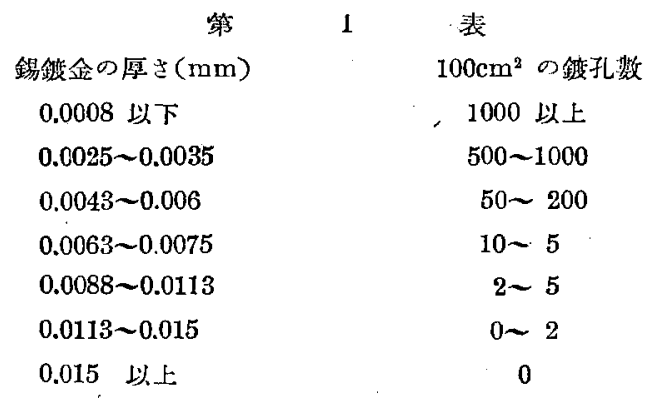

むります。弟 1 表は錫酸ナトリウム溶夜を用ひた場合の錫鍍金

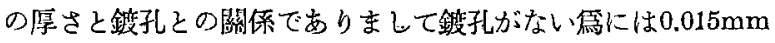
以上を必要と寸る譯であります。乾式鉞金についてはデーター を頂いて計算しましたが曆さは $08 \mu$ 位であります。志賀さん お見えになつて居りますか一志賀さんからブリキ板のピンホ ールの問题について括話願ひたいと思ひますが 一結局祀式鍍 金は短洔間に鍍孔の少いものが得られますが濕式鉏金では長時 閒を姴しますためブッキ板製造には乾式に及ばぬと思ひます。

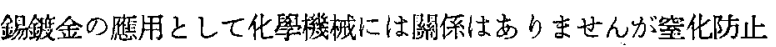

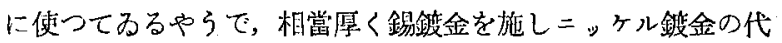
りとして居ります。

尚こ」に一つ鍍金關係として問題がありますのは，從來鐵に

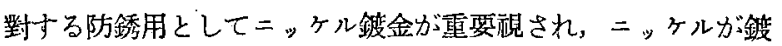
金の 85 90\% を占めて居つた狀態であります。ところがニッ ケルが段々使用出來なくなり，何かニッケルの代りになるすの をといる希望が非常に多いので寸が，ニッケルの代りになる鋯 金は未たに得られませんので，私達考へますのにはクローム鍍

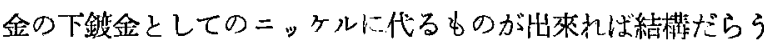

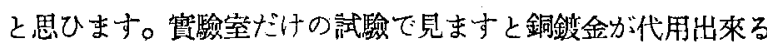
やうに思ひます。筫地試驗をやつて居りませんのでハッキリし たことは判りませんが，或程度错用に供されると思ひます。作 
し銅を用ひるといふことも問題でありますし，及，銅のやうな 赤味のある金屬を下飭金とする事も面白くない。何とか錫のや らな白い金屬を下镀金として用ひたいと考へ，錫と銅の合金鍍 金をやつて居ります。防銹として效果があるやうであります が，機械的性筫が惡いので更に研究を進めて居りまず。

鉛(座長) 甚だ結㮖な御意見で，今のお話では電氣鍍金したも のより倝式の方が强い，樂に行く，ピンホールも少いやろたと いふ話ですが，特に化學機栈などでは形が種々樣々になつて 居りますから，乾式錫金ならば面倒であるが，䉓氣錫金ならば 樂に行けるところもあるだらろと思ひます。次に根岸さんどろ ぞ........

\section{電氮材料としての錫}

根岸元凱(住友電氣工業)，私の方で錫を使ふのは，化學方面で なく、電氘材糊のうであります。先程御話がありましたゴム線 の心線に使子銅線に，錫鍍金を施します。銅は御承知の如く出 來る丈節約しなければならないので，電線も次第にアルミニウ ムに愁へ橙といふ情勢にあります。從つてこの方面の錫の需要 も，寧ろ減つて來ることい思ひます。錫は又珪銅線や烸青銅線 の製造に使ひます。珪銅線では錫 1〜2\%，燐青銅線では $3 \sim 7$

入つて居ります。珪銅線す上述の理由で使用は減つて來る ことい思ひます。橉青銅線は一寸良い代用品がありませんが， この方の需要は大したものではありま产せ。次に電線の接續に ハンダとして錫を使ひます。この方も先の理由で需要は寧ろ減 ること思はれます。ケープルシースの鉛被を强くするため に，錫を3\%ばかり入れた錩を使ることがありますが，今では 硬化莜として多くアンチモニーが加へられます。ケーブルシー ス用の鉛も資源が少いので代用が考へられて居ります。アルミ ニウムで代用しようといふのが一つの案で目下研究を進めてる ます。錫が豐富になるので錫で代用しやうといふのも一つの案 で，研究に着手しました。錫は傎段が非常に高いから，全般的 に置換へられるかどうか疑問ですが，鉛に比して强く且つ此重 が小さいので：シースを薄く輕くすることが出來る利點があり ますから，特殊の方面に使はれるか女知れません。今一つ錫の

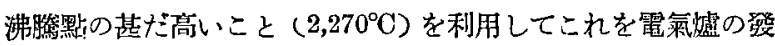
熱體に用ひることが私の方の會社で考案されて居ります。

鉛(座長) 有難らございました。鍇もビルマの北のオが平和に なつたならば出易くなると思ひます。鉛のケープルの代りに錫 を使つて見たらどうかといふのので，試作されてるるといふ括 ですが，これも大分問題になつてるるやうで，いろんな方面に

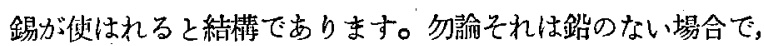
鎴があれば䦗題にならんでせろが……。次に山冈博土に何 か化學機械方面に對する踢の利用について抬話がありました b......

\section{化學機械方面の錫}

山肉淑人(藤永田造船) 化學機㭜方面に錫を使つてるるのはポ ンプパルブとが熱交換器であります。西村博士の云はれた通り 銅が相當要りますから，油と加硫黃の加工に對寸る而触性とし て溫度が少し高いからどらかと思ひますが，精溜塔のキャプに 亞鉛鎨金とかクローム䤵金をやつて居りますが，さらいふとこ ろの转金に使つたらどらかと思ひます。禹角キャプのところに 銹が固まつて油の流れ施が惡くなりますからなるべく褋びない 方がいると思ひます。

鉛(座長)それは研究を蛙進めになつて居りますか。 山冈 まだそこまでやつて居りません。たら゙溫度が少し高いて すから，融點の高い、合金にでもしたら……

鉛(座長) 合金で融㪇の高いるのは出來をせらか。 西村 融點が高くなつても化合物を含むるのは共晶合金を作り ますから，熔融開始温度が餘り高くならないやうです。

山㐫さうすると 250 位の程度ですか。

西村 數字で表はすことは控へますが，先程申しました固溶體 の溫度の上る程度に融點の上つて行く性質の金屬になると固溶 體を作つて融點が上ります。さういふすのはフンヂモニーが多 少上るだけで，その他のものは殆どありません。 山內 あの場合には一旦形にしてから鍍金をしますから，力。 餘りむりませんから……。

西村 錫と銅の合金では共晶を作り熔融點が低くなります。 山內 何度位ですか。

西村 今ハッキリした敖字を學えませんが $220^{\circ} \mathrm{C}$ 位になるかと 思ひます。

山內 さうですか，それでは䭾目ですな。

趽(座長) それは何とかいるいる研究して……。

西村 それは研究の餘地はあると思ひます。

鉛(座畏) 化學機械協會の側から特に御出席を願つたのは私か ら御指名致しました 4 人の方であります。その外の方々も多數 御出席になつ居りますので，一々御指名申上げませんから，皆 さん御自旧に打話願へれば結構です。

\section{メタルハス用として}

平井泰造(ラサメ合成化學) メタルバスに使ふささらいる媔 でフルイギチーとか潜熱はォタルバスとして使用寸る場合どう でせらか。

西村 メタルバスに相賞使へると思ひます。

平井 無水フタール酸の反應熱除去にナイターバスを使つて居 りますがナイターバスですと材質が鐵を使ふのて腐蝕され易い 
ですからささいふところに使つて見たいと思ふのですが錫を メタルバスに使用した時に酸化して量が減るとかいふ問題は市 ウりませんか。

西村 溫嘪によつては起ると思ひ产すね，传用し得ることは使 用し得ると思ひます。溫度が高くなる程鐵が狂ふと思ひます。 鉛座長) メタルバスはどの位ですか。

平井 $400^{\circ} \mathrm{C}$ 位です。

西村 $400^{\circ} \mathrm{C}$ 位です上ブルキ板より多少高くなります。少し侵 して柬るかと思ひます。金屬のうちで流机のい上ものは錫が一 番い」です。

平井流動性のい」すのを使ふ之能率がい」のだすが，將來安 く手に入れば相賞そら云ふ方面に利用されると思ひます。

鉛(库長) 安いといふけれども，メタルパスだから或程度まで 酸化して減るのは知れて居りますから，高くてあ知抗てるるで せら。ナイターのやろなものですと消耗する为のでないから。

西村，400 $\mathrm{C}$ 优までですと酸化す少くなります。

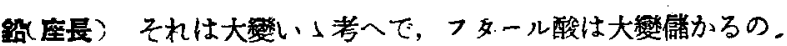
だから........

西村一寸無理かす知れませんね。始終使つてるると鐵を侵し て來るから無理だと思ひます。

ま田辰男(大日本をルロイド) 今のメタルバスの問題ですが， $300^{\circ} \mathrm{C}$ 前後でどらですか。

西村 $3060 \mathrm{C}$ 前後ですと割合にやられないのぢやないかと思ひ ます。鍍金をやるのがそれ位の溫度です。

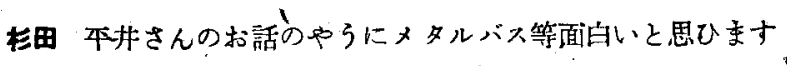
מ゙........

铅(座最) 先程根崖さんの話のあつたのは沸膫點が高いから 盜度の高い時のバスですな。

根岸 發熱體に使ひます。

西村 バスなどは特殊の鋼など侵されないるのを考入ると出來 ます。

\section{チンペストとダレーチン .}

江扵孝之(住友電氣工業) 先程根岸さんからも，鉛先生から。 托話がありましたやうにケーブルシートの代用として錫を使 ふことを考へて居ります。尤もてルミの方研究を進めては居 りますが，錫を使合晴に加工寸るのは容易ですが，いざ使用す るとなるとチンべストが起つてる李す。これが常温でずつと居 つたら，何年位經つとつとグレーチンに變りますか。

西村さらいふことは未だ八ッキり知りませんが恐らく何力喽

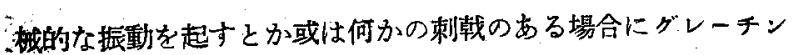
になる悳があると思ひます。

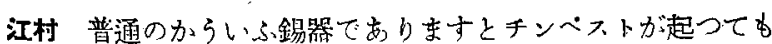
大大したことはありませんが，ケーブルは地下に埋めますると途 中のチンベストを1ヶ所のみに止めるわけに行きまん。續い て擴がると大變なことになり市す。冬など零度以下になつて 2 〜3 年位でチンハストが起るやうですと釦の代用として使へな いと思ひます。

西扵 何かそれに加へてチンの゙スト阼止する方法を考へるよ り代方がないと思ひます。この開も問題になりました。

鉛 座支) チンベストが問題になりました极。何か夾雜物を入 れて防止寸るといふやらな……。

西村 ビスマスの微量などが有效だといふことが書物に出て居 りります。錫は鈖より多少タリープが少いと思ひます。日本では

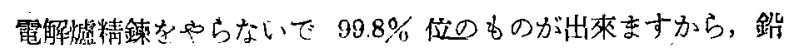
と同じ仿の值段にしてて差支ないと思ひますが……。

\section{錫の耐蝕加工}

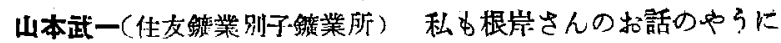
鉛の入手に困難をして居りますので，何とかして共榮圈内で軍

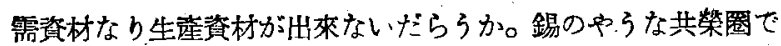
稌亏やらなすのを使つて釦の代用にならないか。では何に使る かといふと耐硫酸性の必要老感じて居りますが，銅の䉓解とか ニっケルの電解，この方面に只今の狀况ではどうしてり鉆が入 りませんので困つて居りますので，少し值段が高くてもいいか ら，錫を何か處理して耐硫酸性の皮膜を拻へるとか，容易に得 られる錫をペースとして過剩に得られる他の金痛を合金として 耐碝酸性の6の办得られないであらろか。今の釦の代りとして 合成樹脂も代用されますが，これは少し私の方で使つてるるも

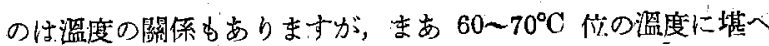
ます。耐硫酸性の錫又は錫合金の皮膜を簡望に掠人る必要を痛 感して居ります。刑にまだ研究むして居りませんが：......。 鉛(座舆) さ引いふ耐酸性とか，殊人耐硫酸性といふすのに對 して錫は如何ですか，西村さん。

西村錫は不十分なやうに思ひますが，今のお話のやうな，こ の間もその話が出て酸化處理のやらな方法で耐酸皮膜が出來な いかといふのですが，まだどれも研究して居りません。

鉛(座最) 十分に研究が潐められてるないといふことは，先程

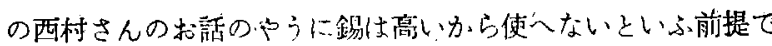
あつたものが，現在ては狳つて來たから，令直ぐてはないにし ても將來非常に方針が變つて來す寸极。これは昨し出來得るて せらね。

西村 確かに゙出來得るとは中筑权ますが，きつて見たいといふ 氮特は致します。

鉛(座長) 先程ブリキの搭が大分出て居りますが，市瀨さん 
一般に化學機珹といふう方面で錫の利用については何か心考へは ありませんか。

\section{化學識械方面の錫の利用}

市瀨元吉(大阪工業試驗所技師) 昔分析をやつて居るものの話 を聞いたのを思ひ出したのですが，酸で處理する特に錫の純度 が岁い上處理し難い名，酸化物が多少でも存在してるると制合 に處理し易いと云つてるました。99.9\%の錫よりも尚つとずつ

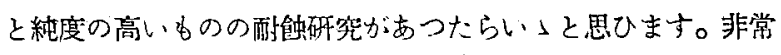
に純粹な錫になると性質が變るのではないか上思ひます。アル ミなど純度が亮くなると性質が變るやらです。

西村－般に金屬の純度がらんと上りますとかなり變つて來ま。

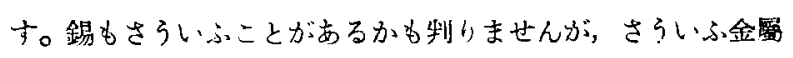
を作ることは相當困難と思ひます。

市瀨ささつき括に出ましたが，硫酸などて倨される機㙌は， 表面に存在する或種の酸化物のやうなもののために早く麻蝕が 起るのてはないかと思ひますが，化學機㭜などに使ふ特に装而 を充分化學的に純粹な形にして置いて酸などに接觸させる。つ 寺り使ふ時にラん上丁寧な方法で使ひ始めたら或は保ちがよく なるだららと思ひます。或は特殊な皮膜を研究して预めつけて をくことも考へられます。

鉛(座長) $99.98 \%$ 以上の金屬といふと非常に純料な金屬で， 實驗窒等でやると性質が變りますが，さういふ純度の高いわの は筫際工業的に安く出來るか否かといふことをすな。 杉田 少し金虽といふのと違つたす百てすが，觸媒としての盟 化錫一特にゴムの誘導體を作る時に必要なのですが一ーさう いふ力方面の從來の需要淕他に就て找敎示願ひたいと思ひます。 西村 別に存じませんが.........

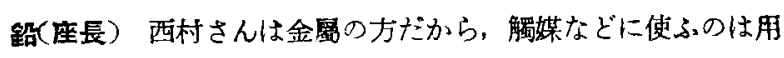
途は割合少ないわけてすな。今日ても觸媒など少ければ態更餙 計使つてい小わてすな。むしろ, 何んな形で使ふといふ意 味でくて，錫といふ子のはやはり立派な金屬ですから，金屬 として使へば一番有效でせうが。

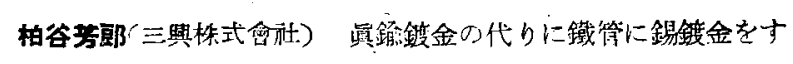
る、それに使へばどらでせらか。

西村 相當有效だらうと思ひ屯す。

鉛（座長）海水に對寸る腐钫といふ心問題で何がりませんか。 これは非常に大きな間題になりますが，香に角合金を考へるに しても先程酉村さんのお話のやうに，銅のやらな足りないるの をべースにして錫を使ふのはいけないので，澤山ある金鹰でや ることを考へないといけませんね。

純錫の鍍金

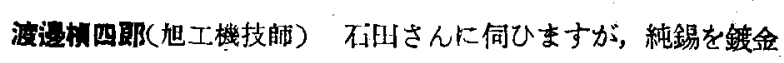
するのはどらすれば最も效果的でせらか。乾式法で行ふ時は少 量の鈗を加へると工作が大變樂になりますが鉛が滥水に溶けま すので工命が惡いのです。例へば蒸溜水製造裝置で蒸氣又は蒸 溜水の觸れる面の鉸金に鉛が少量で混じて居りますと鉛が溶 比して蒸溜水の意味がなくなるといふことが焦々あります。鐵 に純錫を鋅金する事が有效だとしたら，どうしたら最す手取り 早く凡完全に施行する事が出來るでせらか。

石田 乾式鈹金に就ては知りませんので電氣鋉金のみを御話し ます。一般に用ひられて居るのは亞錫酸ナトリウム鋯金液及び 焦性燐酸錫ナトリウム毁金夜であり゙して其の處方は次の通り でります。

\begin{tabular}{|c|c|c|}
\hline \multicolumn{3}{|l|}{ 亞錫酸ナトリウム鈘金液 } \\
\hline 餵化第一錫 & & $40(\mathrm{~g} / \mathrm{l})$ \\
\hline 水酸化ナトりウム & & $80(")$ \\
\hline ザラチン & & $0.5(")$ \\
\hline 溫 度 $65^{\circ} \mathrm{C}$ & 電流密度 & $0.5 \mathrm{~A} / \mathrm{dm}^{2}$ \\
\hline 陽 極 錫 & & （島田氏） \\
\hline \multicolumn{3}{|c|}{ 焦性瀿酸錫ナトリゥム鉏金液 } \\
\hline 酤化第一錫 & & $20(\mathrm{~g} / \mathrm{l})$ \\
\hline 焦性燐酸ナトリゥム & & $50(")$ \\
\hline 酒 石 酸 & & $5(")$ \\
\hline 溫，度 $65^{\circ} \mathrm{C}$ & 電流密度 & $0.2 \mathrm{~A} / \mathrm{dm}^{2}$ \\
\hline
\end{tabular}

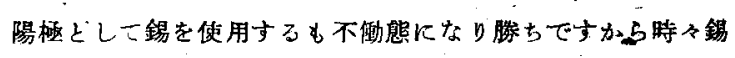
監の㭪給を必要とす。

錫酸ナトリゥム鍍金腋

錫酸ナトリウム

水酸化ナトリウム

過酸化水素

翏狀物留

溫 度 $65^{\circ} \mathrm{C}$

陽極 幟丈はニッケル

時々錫酸ナトリウムの補給を必要とす。

$$
\begin{gathered}
80 \sim 240(\mathrm{~g} / l) \\
10 \sim 50(") \\
2 \sim 4(") \\
\text { 少 量 }
\end{gathered}
$$

霆流密度 $1 \mathrm{~A} / \mathrm{dm}^{2}$

渡遭 先程電氣鍍金ではどンホールが多いといふことでした が, 今の和話の方法によるとビンホールの問題で困難にがつか。 るのではないせろか。

石田 厚さの問題です。厚くなる.とピンホールが少くなりま to

渡邊 乾式の方法でい小方法はありませんか。

鉛(座長)ブリキの摩さはどの位ですか。

石田 $\quad 0.73 \sim 0.94 \mu$ です。

\section{チューブの錪金}

渡傻 我ふが普通コンデンサーチュープの外面に對して施行す る場合も乾式で行ふと施行者が蔳足寸るやらな結果が得られま すまで施行を丁寧にし，又は繰这しで行ふ事が出來ますので出 
來るだけ乾式でやりたいと思つて居ります。美支ない時は若干 鉛を入れて作業を容易にする事もあります。又熟練致しますと 純錫でも十分完全な鍍金を得る事も出來ますが，仕勃がやり難 くなる事は止むを得ません。

是井 化學機械方面では乘角錫は高くて使へない为のと考へら れて居りましたが，これが多量に安く大ることになると，いる んな有機の藥品とか有機の酸等で錫を使つてい」すのが大分あ ると思ひます。今聞きますと鍍金などが難かしくて，ビンホー ルがあるとすると，化學的にはよくてる機械的に加工力゙難かし くなるのではないか。錫を單體として使ら程には潤睪にないで せうから，結局鍚の錪金等の問題をまつ解決寸る必要があると 思ひます。合猃にすれでい小ですが。

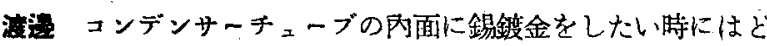
の程度のビンホールが佾內面に存在して居るかを十分完全に检 㚗する方法がないので，それを行つても結果がいのか惡いも のか判りません。從つて實際上實施することが困難かと思ひま すし我々も未だに實施して居りません。

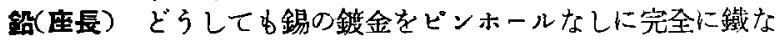
どに附けるといふことは矿田さんあたり早速やつて貪ふんです な。

石田 チューブ類に對しては乾式鏗金になるんぢやないかと思 ひますが........

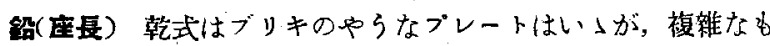
のにみると電氣の方がい」でせう。

\section{メタリコン}

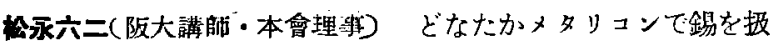

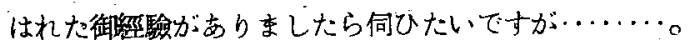

鉛(座長) メタทコンを錫でやつた御經驗の方はあり、せん 加

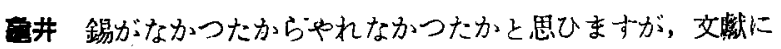
はあります。

松永 研究したくもやれない。

鉛(座長) 錫は使ふべきものでない。使へんと思つてるたから …....

松丞チェーブの网側は䭾目ですけれども，外側ならば電氣鍍 金よそビッホールがましではないかと想像致しますが……
鉛(座長)この間大阪市の發明裴影でメタソコン工場を見まし た。不四涒も一緒でなかつたですか。あれなどピンホールがな いやうですね。

石田 西村先生に招尋ねしたいですが，錫 40\%，銅 60\% 位の 合金は，食罢に過酸化水素を入れた溶液に對し耐玲性がありま

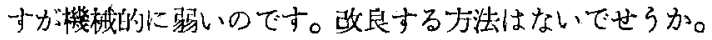

西材 非常に脆いものではありませんか。

石田 脆いゅのです。

西村さらいふものは他の合金にも澤山あります。耐蝕性を問 題にすれば化合物の出來る筈圍冈で强いものがあります。

石田 中へ何か.........

西村・大れても䭾目です。本來の性質ですから止むを得ないて す。

渡僈 松川さんにお㝷ねしますが錫をバスメタルの材料とする 場合にどろいふ風な合金としたら最も具合のよい專用のバスメ タルとする事が出來ますでせらか。溫度は假に３00 $\mathrm{C}$ 位と致し ませろっ

松川ヒニーズメタルになりますが……‥ 鉛とかビスマス など入机ればよいでせらが……固まるまで领却てて…‥ 膨脤が激しく非常に比重が多いですから溶けてしまひます。何 かで押へつけなければなりません。

閉睘

鉛(座長) まだ少し時間がありますがメーカー側の力か工場 侧の方で何か御賢問であ御意見でもありましたら……。

それでは別段括もないやうですから，これで座談會を開會 致します。終りに臨しで座談會の基を作つて頂きました西村呚 授に對して厚く御柕豊申上げます。

份皆さん方長時間に涉りいろいろ化學根械協會側としてb洵 に有益なる拉話を伺ひ有難引御座いました。

錫の利用關係に就きましては色々括考へもありませろから敢 て今日の座談會と云はず，國家のために最も重要な問題ですか

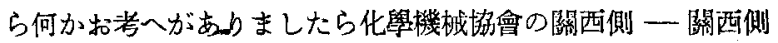
と限りませんが一に宛て」御意見を述べて頂ければ，協會誌 を通じてこれを墢装することも出來ますので，どらか御通知願 ひたいと思ひます。座談會はこれで閉會致します。

（文害在螎䐕） 